IRA-International Journal of Management \& Social Sciences

ISSN 2455-2267; Vol.06, Issue 03 (2017)

Pg. no. 391-410

Institute of Research Advances

https://research-advances.org/index.php/RAJMSS

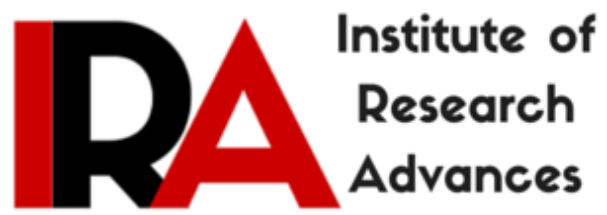

\title{
Black Economic Empowerment, Employment Creation and Resilience: The Economic and Social Contribution of Lennox Mine to the Development of Zimbabwe, 1970-2016
}

\section{Davidson Mabweazara Mugodzwa}

Lecturer in Economic History, Department of History and Development Studies, Great Zimbabwe University, Zimbabwe.

Type of Review: Peer Reviewed.

DOI: http://dx.doi.org/10.21013/jmss.v6.n3.p6

\section{How to cite this paper:}

Mugodzwa, D. (2017). Black Economic Empowerment, Employment Creation and Resilience: The Economic and Social Contribution of Lennox Mine to the Development of Zimbabwe, 1970-2016. IRA-International Journal of Management \& Social Sciences (ISSN 2455-2267), 6(3), 391-410. doi:http://dx.doi.org/10.21013/jmss.v6.n3.p6

(C) Institute of Research Advances

\section{(cc) EY-NC}

This work is licensed under a Creative Commons Attribution-Non Commercial 4.0 International License subject to proper citation to the publication source of the work.

Disclaimer: The scholarly papers as reviewed and published by the Institute of Research Advances (IRA) are the views and opinions of their respective authors and are not the views or opinions of the IRA. The IRA disclaims of any harm or loss caused due to the published content to any party. 
ABSTRACT

This research sets out to unravel the history of Lennox Mine from its inception in 1970 tracing the contribution of the mine to the economic development of Zimbabwe from its colonial beginnings up to the current period when the new visionary owner, Honourable Gandiwa Moyo, Deputy Minister of Mines who inherited a dysfunctional mining enterprise set it on course again as a pillar for economic production, under the erstwhile management of the Lennox General Mine Manager, Edgar Mashindi. The research seeks to explore how the mine management, operating under harsh economic conditions prevailing in Zimbabwe has empowered African entrepreneurs and employees and resuscitated life to the dying town of Mashava. Mashava is back on its former footing as a lively booming bedroom town of Masvingo City, forty kilometres away: supermarkets, bars, salons, housing projects, new shops are sprouting up once again as Mashava claims its proud place as a gold producing enclave of the Zimbabwean economy. Hundreds of unemployed youths from all over Zimbabwe have descended on Mashava, seeking employment and investment opportunities resulting in an unprecedented economic boom which is being felt country wide. Only recently hordes of flea female market traders opened shop at Mashava to sell clothes, shoes, household furniture and related paraphernalia to local residents and they reported that business was excellent and confirmed business plans to return every month end to sell their wares. A few years back Mashava was an abandoned mining town with all services shut down after the Capitalist oligarchic organization which owned Mashava ceased all operations and expropriated capital to Australia and Europe and started out new commercial ventures in those respective European countries. The Zimbabwean Electricity Supply Association [ZESA] shut down electricity supplies to Lennox Mine after the mine incurred a debt of close to a quarter of a million. Today, Lennox has agreed on a payment plan and electricity has been reopened triggering high gold productivity as the mine returns to its normal production levels.

Key words: Empowerment, production, prostitution, brutalization, environment, accommodation and proletariat

\section{ABREVIATIONS USED IN THE TEXT}

A.N.C -Assistant Native Commissioner

B.S.A.C -British South African Company

C.N.C- Chief Native Commissioner

MDC-Movement for Democratic Change

M\&R- Murray and Roberts

N.A.D.A-Southern Rhodesian Native Affairs Department

N.C-Native Commissioner

ZANU [PF] - Zimbabwe African National Union [Patriotic Front]

ZESA-Zimbabwe Electricity Supply Authority

ZWD- Zimbabwe Dollar

\section{Methodology}

This research is mainly based on oral research amongst current employees and former employees and management of Lennox Mine from its inception up to the present day when the visionary leader Engineer Gandiwa Moyo has resuscitated the defunct mine to its current vibrant and high production level, under the management of the Mine General Manager, Edgar Mashindi. I identified former and current employees who enabled me to explore the history of the mine from the colonial period throughout to the independent and post-independent era.

This research was also informed by documentary evidence from archival and related secondary sources. 
Mine publications and mine records of production were consulted to furnish the history of the mine under European management. Native Commissioner Records pertaining to the pre-colonial and colonial era are largely available at the National Archives in Harare and these will be thoroughly analysed to extract data relating to Lennox Mine. Basically, the main primary sources of information for this research were the male and female employees and former employees of Lennox Mine. Residents of Mashava who were be selected for interviews. Mashava is historically blessed with a sizeable population of elders who have defied time and enjoy longevity. Some of these elders are immigrants from Malawi who were recruited for mine labour during the colonial period and they shed light on what really transpired during their hey days at Lennox Mine. These custodians of oral history, traditions, cultural and religious practice were willing to tell the story and be recorded being only too well aware that this history is being kept safely for future generations to come.

The historical approaches include patience, endurance; excellent listening skills and well-developed stamina coupled with good sense of humour and tolerance, the history of Lennox Mine was then recorded and stored for posterity. Oral interviews were conducted personally by the researcher to enable close interaction and probing. Eye contact with the informants enabled the researcher to assess the validity and historical worthiness of the oral information being collected from the elders. Further probing helped the researcher to follow-up on unclear statements, insinuations, assertions and exaggerations when the information was being collected from the elders. The researcher was clearly aware of the limitations of oral sources but the collected data corroborated with data from writen Mine records as well as colonial documents. Mashava has abundant data writen by the respective native commissioners of Chivi and Charter dating back to 1895 .

The researcher has collected, analysed and employed oral traditions in the past and has specialized in this for several years now leading to many published documents pertaining to pre-colonial communities in Zimbabwe. Only elderly women and men who are former employees and residents of Mashava were sampled for interviews throughout Mashava residential surburbs of King Mine, Gaths Mine and of course Lennox Mine. The researcher employed the usual expertise and experience to select suitable informants including traditional leaders, prominent elders, neighbouring peasants and also commoners in and around Mashava.

The purposeful sampling procedure was adopted in this paper as I had to identify elderly former employees at Lennox Mine and Mashava. I personally sought their trust and permission to interview and record their views at their homes and work places. Documentary evidence was consulted and a large array of colonial writen records is available at the National Archives in Harare. These writen documents have obvious bias since they were recorded by colonial employees of both Lennox Mine and the BSAC. However, the same documents describe the social, economic and political organization of indigenous people at great length. Little attention is accorded to gender issues especially the history of women in mining production or the use of child labour by European capitalist enterprises which occurred on a large scale in European mining and farming enterprises. In line with this view NC Posselt reported that young boys were no longer interested in working for Europeans because of low wages and brutalization by these employers, especially those of Dutch origins. He reported, "...it is lamentable to record that there is a growing disinclination amongst the boys of from 12 to 17 years of age [i.e. children below 18 years old] these boys came out and were eagerly employed now it is with utmost difficult that a youth can be induced to enter service..." The same colonial documents are silent about the role of women in economic production in the mining sector. Therefore these colonial documents will be subjected to the usual historical scrutiny and corroborative evidence will be offered by oral traditions collected from different employee groupings in Mashava. Written and published secondary documents will also be analysed to shed light on similar situations in Africa.

\footnotetext{
${ }^{1}$ N9/1/12 Annual Report 31 December 1913
} 


\section{$\underline{\text { Introduction }}$}

Mashava which was formerly called Mashaba is a mining town in Masvingo Province, Zimbabwe and is located $40 \mathrm{~km}$ from Masvingo along the Bulawayo-Zvishavane Highway. Mashava was once a thriving asbestos and gold mining town comprising urban communities of both white and black mine workers who derived their existence from selling their labour power to the mining conglomerates. Asbestos was mined at Gaths Mine and King Mine while gold mining was carried out at Lennox Mine.

Mashava now currently shows signs of recovery after suffering environmental neglect characteristic of a shanty town when the Government of Zimbabwe had failed to channel in infrastructural and maintenance development programmes to keep the town on a sound footing after the closure of all asbestos and gold mining activities. Sadly clean water is still not available on a regular basis and electricity supply to the town is chaotic and sometimes major areas of Mashava are cut-off for more than two or even three days a week. $^{2}$ All Lennox housing units have been without electricity for many years now after the gold mining enterprise incurred a credit balance of nearly a quarter of a million dollars to ZESA ${ }^{3}$ [Zimbabwe Electricity Supply Authority], the regulatory board supplying electricity to Zimbabwean citizens. It is only in early January 2017 that the Edgar Mashindi Management Team at Lennox Mine successfully negotiated a payment scheme accceptable by ZESA that electricity has been restored at the mining complex. ${ }^{4}$ Water flows in the old tapes only twice a week and is always filthy from the rusty pipes. ${ }^{5}$ This deplorable state of affairs has caused related illnesses amongst several Mashava residents and to make matters worse underground water is heavily polluted by the dumping of asbestos and gold mining waste into the nearby rivers and streams. ${ }^{6}$

Asbestos mining operations have ceased stopped at Gaths Mine and King Mine ${ }^{7}$ thus Lennox Mine remains the only viable current economic productive sector in Mashava and is the life line of all residents in the area as well as unemployed youths from all over Zimbabwe who have descended on the town to seek employment and investment opportunities. ${ }^{8}$ Chrome mining is taking place on a meagre scale at King Mine and illegal chrome mining activities are threatening lives of residents who dwell here as these illegal miners also called Makorokoza dig anywhere even under existing housing units for the lucrative mineral which they sell on the black market. ${ }^{9}$

The Mashava Asbestos Mines were only as recently as the early 1990s part of Shabani and Mashaba Mines owned by the Turner and Newell Capitalist oligarchic corporation who then sold both mines to Zimbabwean business mogul, Mutumwa Mawere for sixty million British pounds [ $£ 60000$ 000.00] in a deal sponsored by the World Bank. ${ }^{10}$ Both mines are now under the Zimbabwean Government control after Mutumwa Mawere was forced to flee the country, fearing for his life when trumped up charges were leveled against him by some members of the current ZANU [PF] Government. ${ }^{11}$ The two mines produced asbestos and Gaths Mine produced the longer fibre, which is popular on the international market. Since the illegal nationalisation of the asbestos mines, the international community has banned the trade in Zimbabwean asbestos in retaliation for the failure to service the loan which Mawere procurred the mines

\footnotetext{
${ }^{2}$ Interview with Raymond Kechi, Lennox Mine resident, 12 January 2017

${ }^{3}$ Interview with Edgar Mashindi, the Lennox Mine General Manager, Lennox Mine, 2 January 2017

${ }^{4}$ Interview with Edgar Mashindi, the Lennox Mine General Manager, Lennox Mine, 2 January 2017

${ }^{5}$ Interview with Gandiwa Tariro, Lennox Mine Director, Lennox Mine, 6 January 2017

${ }^{6}$ Interview with Trust Muganje, Businessman, Highway Nightclub, Mashava, 16 January 2017

${ }^{7}$ Interview with Tinei Mumbamagwo, former employee, Gaths Mine, 15 January 2017

8 Interview with Tasara Muguti, Lecturer in Economic History, Great Zimbabwe University, Mashava Campus, 12 January 2017

${ }^{9}$ Interview with Honourable Member of Parliament, Ezra Chadzamira, Mashava, 21 January 2017

${ }^{10}$ Gaths Mine Report, 1990:1

11 Telephone Interview with Mutumwa Mawere, South Africa, 22 January 2017
} 
from Turner and Newell. ${ }^{12}$

D.S.O. Mine and Boss Mine are private mines also situated in Mashava but both these mines shut down many years ago. ${ }^{13}$ Bere Township is also a Mashava High and Low residential area which was created to supply cheap labour to the once flourishing asbestos and gold mines. ${ }^{14}$ After the closure of the asbestos and gold mines in Mashava many years ago, very little development has taken place in this area despite operating for nearly a century. ${ }^{15}$ The town centre is occupied by Highway Supermarket which is the main shopping centre, a single private petrol station has now opened shop at Mashaba Motors and another petrol service station at Magwizi ceased operations many years ago and a police station mainly built of wooden structures runs a small remand prison that houses the notorious makorokoza who have fought each other using pangas and machetes over disputed gold ores from Lennox mining complex.

\section{Historical background of Mashava}

This research is an attempt to investigate the socio-economic and environmental impact of gold mining at Lennox in Mashava. This area was originally a rural enclave inhabited by the Karanga ethnic group who pursued a vibrant peasant economy largely based on agriculture and livestock keeping. ${ }^{16}$ This presentation will therefore give a brief description of the Mashava environment on the eve of colonial rule in order to enable a comparative analysis with the situation now prevailing in the same area, nearly a hundred years after the gold mining enterprise was introduced. The traditional land tenure system operating in Mashava before the advent of British colonial rule was negatively transformed by the capitalist economic system which affected peasant production and ushered in the development of underdevelopment at Mashava.

Mashava was part of Chibi District [now called Chivi] and largely inhabited by the Karanga people. ${ }^{17}$ It was bordered to the north by Charter District which was also inhabited by Karanga speaking people. Mashava had generally a Savanna woodland type of vegetation and the north - eastern part of the area was a dense forest where many varieties of trees thrived. ${ }^{18}$ Mashava shared the northern border with Charter District and the Mashava Range marked the geographical boundary between the two districts which were both occupied by Karanga speaking people. ${ }^{19}$ On the watershed of Mashava, the Musasa tree grew in great abundance and the bark of this tree species used for multi-purposes by the local population, such as making blankets [called daunha], fish and game nets [called mambure]. The Karanga people also used the same bark for making very strong rope [called gavi] used for thatching huts and other similar purposes. The north-eastern part of the Mashava is what local people called Mutao forest. In the Mutao Forest, the Mopani, the black olive tree naturally thrived. ${ }^{20}$

Mashava had a generally mild climate except in June and July which had cold winds, often accompanied by frost. ${ }^{21}$ However, the climate varied slightly in different parts of the area under research. Rainfall was heaviest between November and January. The bordering Chibi District in the south was however notorious for periodic droughts. ${ }^{22}$ The principle grain cultivated by the Karanga people of the area included finger millet [called rukweza], and this was grown mostly in the wetter Highveld areas, bulrush

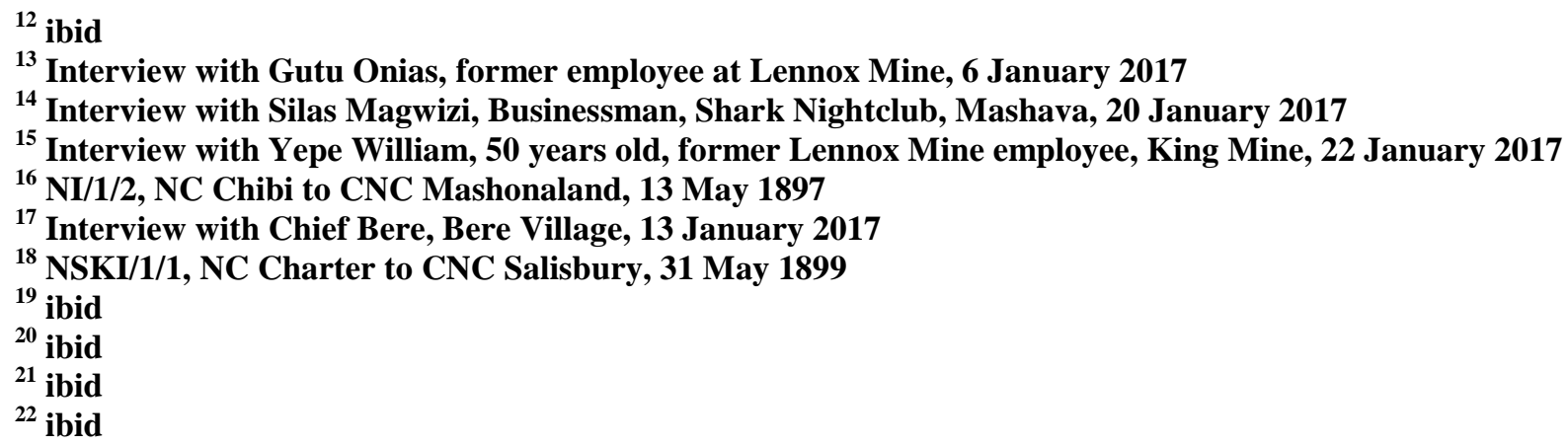


millet [mhunga] and sorghum [mapfunde] The indigenous people also grew subsidiary crops such as rice [called mupunga], groundnuts [nzungu], ground beans [or nyemba], cowpeas [nyimo], maize [chibage], and some different types of vegetables including pumpkins [manhanga], cucumbers [magake], gourds [matende] and many others. ${ }^{23}$ Mhunga, a drought resistant cereal crop was the staple food for the Karanga and it was grown in large quantities in the drought-ravaged Chibi District. Maize, introduced into the country by Portuguese traders, did not become a staple crop until the twentieth century because it was said to be difficult to reduce it to mealie-meal. ${ }^{24}$

Documentary evidence suggests that the Karanga people in Mashava were basically agriculturalists and thus agriculture was the mainstream of the economy before colonial rule. ${ }^{25}$ However, there were also other economic activities such as hunting, gathering, fishing, manufacturing, [making bark clothes, blankets, fish and game traps, ropes, baskets, pottery etc.], building [huts, cattle pens, fencing homesteads and fields], iron smelting and trade. ${ }^{26}$ These were however, only secondary economic activities which were done during the agricultural off-season or when there was drought [called shangwa]. Written evidence shows that the Karanga agricultural system in Mashava was relatively successful but the major constraint was periodic droughts. ${ }^{27}$ Iron hoes [mapadza] obtained from trade with the Njanja people of Charter District were used on a large scale and this boosted agricultural production. ${ }^{28}$ The Njanja traders preferred to receive cattle in exchange for their hoes ${ }^{29}$ Iron hoes were also exchanged for goats and sheep at the rate of two or three hoes for a small goat/sheep. ${ }^{30}$

The iron hoes revolutionized food production. The hoes together with axes [matemo] were used to great effect in preparing new and old fields for cultivation. Agricultural land was abundantly available and was communally owned. There was plenty of land for everybody, however only married male persons had access to such land. Women owned small gardens where they cultivated mainly vegetables such as manhanga, tsunga, nyevhe and many others. However, upon the death of the spouse, the surviving female owned and cultivated the fields of her deceased husband. ${ }^{31}$ Land was distributed by the chief [mambo] to his respective headmen [masadunhu] who in turn distributed it to male family heads. Chief Bere was the local chief of Mashava area. ${ }^{32}$ [Interview with Chief Bere, 66 years old, Bere area in Mashava, 24 January 2015]

Cattle-keeping was also a major source of wealth for the Karanga people of Mashava and during years of drought cattle were sold in order to procure grain from those families who had surplus. ${ }^{33}$ During the colonial people, cattle were also sold to meet tax obligations. ${ }^{34}$ It is thus our argument that the introduction of taxation by the BSAC marked the beginning of a long period of systematic impoverishment of the peasantry by a colonial economic administration. The Karanga people of Chivi seem to have had large herds of cattle as observed by NC Taylor. ${ }^{35}$ Cattle were also important as baggage

\footnotetext{
23 ibid

${ }^{24}$ N3/1/5, NC Charter to CNC Salisbury, 26 August 1903

25 ibid

${ }^{26}$ NSKI/1/1, NC Charter to CNC Salisbury, 31 May 1899

${ }^{27} \mathrm{~N} 3 / 1 / 5$, NC Charter to CNC Salisbury, 5 December 1899

28 ibid

${ }^{29}$ Mackenzie J.M, “A pre-colonial industry, the Njanja and the iron trade”, in NADA, $1975,11$.

${ }^{30}$ NSKI/1/1, NC Charter to CNC Salisbury, 31 May 1899

${ }^{31}$ Interview with Chinoti Muguti, peasant farmer, Bere Village, 21 January 2017

${ }^{32}$ Interview with Chief Bere, Bere Village, 13 January 2017

${ }^{33}$ N9/1/8, Annual Report, 31 March 1903

${ }^{34}$ N9/2/1, Half-yearly Report, 30 September 1897

${ }^{35}$ N9/1/7, Annual Report, 31 March 1901
} 
animals. They were also crucial in bride wealth $[$ lobola $]$ payment. ${ }^{36}$ Therefore cattle played an important part in the Karanga economy during both the pre-colonial and colonial periods. Cattle were also used as a form of exchange in the procurement of hoes, axes and other daily needs. ${ }^{37}$ The Karanga people of Mashava were also engaged in local internal trade to obtain essential commodities like salt and hoes from Charter District. David Beach has noted that, "...the best known salt-producing area was the middle Sabi valley." 38 The Hera people of Nyashanu were involved in salt manufacturing in this area and they sold it in areas such as Bikita, Mashava and others were it was scarce. ${ }^{39}$

I have attempted to demonstrate that because of the availability of land accompanied by a successful agricultural and animal husbandry system, poverty on a large scale was non-existent amongst the peasantry Karanga speaking people of Mashava before the advent of colonial rule. My argument is that poverty and the subsequent environmental degradation occurring at Mashava were the creation of the establishment, operation and management of a European capitalist oligarchic mining enterprise there. On the whole, I have attempted to show that the economy of Mashava during the pre-colonial era was independently developing. Mashava area also corresponds with Walter Rodney's definition of development, because the Karanga people were independently, “...increasing their capacity to extract a living from the natural environment and ability to support a growing population." 40

The economic situation prevailing in Mashava area after the introduction of colonial rule completely transformed peasant production and conservation practices. European capitalist farming and mining activities shattered the existing robust peasant economy. Taxation and loss of land greatly contributed to the impoverishment of the Karanga peasants. ${ }^{41}$ All adult males were forced to pay tax which initially they met by selling grain to local dealers but during periods of drought, the Karanga sold off their cattle to European commercial ranchers at next to nothing prices in order to raise the money to pay taxes. ${ }^{42}$ The Karanga were not at all enthusiastic to register for any farm or mine labour on European capitalist enterprises because they could easily meet their taxation obligation through agricultural and livestock production. ${ }^{43}$ According to J.M. Mackenzie, BSAC officials and European settlers argued very strongly that the development of Southern Rhodesia was being retarded by the reluctance of the African population to go to work. ${ }^{44}$

In an attempt to resolve the perennial labour shortage in the colony, the British South African Company [BSAC] initially introduced various mechanisms such as boosting the population of Africans in Rhodesia by inviting foreign Africans from South Africa to come and settle in Rhodesia. ${ }^{45}$ The Fingos were targeted for this promotional immigration into Rhodesia. Other African groups were invited from Portuguese East African territory, from the Northern Transvaal and from Bechuanaland. ${ }^{46}$ Some of these arrangements were said to have been secretly made. ${ }^{47}$ The Chamber of Mines in Southern Rhodesia also encouraged immigrant labourers from Northern Rhodesia and Nyasaland to bring their wives and children

\footnotetext{
${ }^{36}$ NSKI/1/1, Monthly Report, 31 March 1899

${ }^{37}$ Mackenzie J.M, "A pre-colonial industry, the Njanja and the iron trade”, in NADA, $1975,11$.

${ }^{38}$ Beach D.N, 1977, “The Shona economy: branches of production”, in R. Palmer and N. Parsons, [eds], The roots of rural poverty in Central and Southern Africa, Heinemann, London.

39 ibid.

${ }^{40}$ Rodney Walter, 1980, How Europe underdeveloped Africa, Zimbabwe Publishing House, Harare, p51

41 Interview with Chief Bere, Bere Village, 13 January 2017

${ }^{42}$ Interview with Silas Magwizi, Businessman, Shark Nightclub, Mashava, 20 January 2017

43 ibid

${ }^{44}$ Mackenzie J.M, 1974, 'Colonial labour policy and Rhodesia', in Rhodesian Journal of Economics, 8

45 ibid

46 ibid

47 ibid
} 
to settle permanently in Southern Rhodesia. ${ }^{48}$ All these attempts to lure foreigners to settle in Southern Rhodesia to act as labour reserves proved a complete failure for a variety of reasons. The Somalis and South Arabians who arrived in Rhodesia in 1900 and 1901 proved unsuitable for mine labour, in fact one group rioted in Beira and the whole exercise was scrapped. ${ }^{49}$

As a result of this labour shortage some European mining companies were employing Africans from Nyasaland [now Malawi] registered by Recruiting Agents operating there. ${ }^{50}$ NC Posselt observed that, "...the Nyasa labourers with the exception of a few are giving satisfaction, the employers experience some difficulty with their language otherwise the relations between master and servant are satisfactory.... ${ }^{, 51}$ I must state that despite the introduction of African labourers from Nyasaland the labour shortage still remained unsolved. Even NC Posselt noted that, “...local employers were very short of labour..." ${ }^{, 52}$ Migrant labourers from the Cape in South Africa did not prove useful because of the poor working conditions on mines in Southern Rhodesia where the workers were subjected to long working hours and grossly underpaid. ${ }^{53}$ Furthermore N.C. Posselt observed that mine workers were starved on poor diet and housing conditions were appalling. ${ }^{54}$

This paper notes that Malawian migrant workers were thus recruited and resettled in Mashava as cheap labour reservoir for the mining enterprises. Informants have established that the response of local peasants in the surrounding Mashava area of Southern Rhodesia to labour recruitment for mines was not initially positive. ${ }^{55}$ Pertinent to this investigation is the view that, in fact there was no labour shortage in Southern Rhodesia at all: but rather the colonial capitalist enterprises were financially handicapped to enable them to pay adequately and fairly pay for African labour. ${ }^{56}$ At the same time documentary evidence shows that African peasants in most of Southern Rhodesia region were in fact producing surplus grain and livestock for sale at a profit and did not need to work for Europeans to accrue cash. ${ }^{57}$

Both NC Taylor and his successor NC Posselt noted the reluctance of Karanga peasants into registering for labour. Both Native Commissioners completely missed the point when they interestingly attributed the lack of interest to work amongst the peasants as due to sheer laziness. Even as late as 1914, South Rhodesian peasants in general did not show any slight inclination for working for the European capitalist enterprise. NC Posselt reported that, "... although a substantial increase in the number who want to work can be shown over last year there is no doubt that a general reluctance exists among natives to go and work at all..., 58

NC Posselt described this labour as being of an 'inferior' quality only suitable for surface mine work. He also warned that, "... as long as the natives have no pressure they will not and need not work..."

\begin{tabular}{l}
\hline${ }^{48}$ Ibid. \\
${ }^{49}$ ibid \\
${ }^{50}$ ibid \\
${ }^{51}$ N9/1/12, Annual Report, 31 December 1909 \\
${ }^{52}$ N9/1/14, Annual Report, 31 December 1911 \\
${ }^{53}$ Mackenzie J.M, 1974, 'Colonial labour policy and Rhodesia', in Rhodesian Journal of Economics, 8 \\
${ }^{54}$ N9/1/16, Annual Report 31 December 1913
\end{tabular}

${ }^{55}$ Interview with Silas Magwizi, Businessman, Shark Nightclub, Mashava, 20 January 2017

${ }^{56}$ Interview with Chief Bere, Bere Village, 13 January 2017

${ }^{57}$ N9/1/17, Annual Report, 31 December 1914

${ }^{58}$ N9/1/17, Annual Report, 31 December 1914

${ }^{59}$ ibid 
Posselt attributed this reason to economic factors such as the possession of, “...unfortunately unlimited ground for cultivation, unlimited food supplies..." ${ }^{60}$ Europeans were thus generally angry that Africans had adequate food and farm lands which enabled them to pursue a semi-luxurious peasant existence which was both self-sufficient and self-sustaining. ${ }^{61}$ It is my argument that European enterprises deliberately set forth mechanisms which destroyed peasant production in order to force the Africans into the European capitalist labour market. This they did with remarkable success and thus ushered in an era of rapid impoverishment and environmental degradation of a formerly rural self-reliant peasantry economy.

\section{The socio-economic impact of Lennox Mine on the Zimbabwean economy}

This research seeks to investigate the contribution of Lennox Mine to the development of Mashava in particular and Zimbabwe in general. Lennox Mine was established in 1970 and was one of the first gold mines operating at full throttle in Zimbabwe. The research traces how Lennox Mine transformed the livelihoods of Karanga people who are the original inhabitants of the formerly rural Mashava area in Chibi District. Furthermore, in this research I also seek to unravel the impacts of the closure of the same mine on the livelihood struggles of the same inhabitants of Mashava whose existence now totally depended on the mine.

The research will analyse the infrastructural development established by Lennox Mine in Mashava and investigate how this impacted on the community. I will also explore community development projects which the Mine initiated. Establishment of towns always have both negative and positive impacts on the rural communities where such developments sprout. It is my intention to trace such impacts in Mashava and establish whether the rural communities benefitted from the gold mining operations taking place in their backyard. Mining as an enterprise is labour and capital intensive : Lennox Mine as expected recruited labourers so as to maintain a reliable labour reservoir in Mashava. How did foreign labour recruitment affect the social and cultural organization of the Karanga people who were the indigenous population? I will examine the impact of Malawian and other foreign immigrant labourers' settlement in Mashava on the indigenous population. How did the Karanga receive the new immigrant population who came from far-off countries to live and work in their area ? The reseearch will trace the social interaction and relations between the Karanga and the new ethnic groupings who were thrown in their midst.

There is very little literature on the establishment, operation and management of Lennox Gold Mining in Mashava. This paper is definitely a pioneer on the subject under discussion. Microsoft Encarta Encyclopedia has given elaborate details about how rural communities have often benefitted from mining corporations. ${ }^{62}$ Microsoft Encarta Encyclopedia has argued that, mining corporations in so called Third World Countries like Zimbabwe often usher in economic and social benefits to the local communities in which they operate. ${ }^{63}$ Mining conglomerates create employment on a large scale, usher in development of infrastructure and generate funding of community projects such as building of schools, clinics, recreational facilities and many others. ${ }^{64}$ This publication however dwelled on the impacts of large mining conglomerates and Lennox Mine is not really a large scale mining enterprise. Above this, the Encyclopedia only analyses positive impacts while paying little detail about the negative impacts of large scale mining.

\footnotetext{
${ }^{60}$ ibid

${ }^{61}$ Interview with Chief Bere, Bere Village, 13 January 2017

${ }^{62}$ Microsoft Encarta Encyclopedia, 2000, Mining benefits streams, Washington, USA, P14

${ }^{63}$ ibid

${ }^{64}$ ibid
} 
The World Bank Report, 2005, recognized that a country's economic development is strongly linked to its mining infrastructure. ${ }^{65}$ Infrastructure is presented as a catalyst that propels a country or community's ability to expand trade, cope with population expansion, reduce poverty and a host of other factors that define economic and human development. ${ }^{66}$ For example, Murowa Diamond Social Review Community Bulletin, argued that its development plan included the successful construction of the Nyamwa Dam on the Runde River which directly benefitted the community by providing clean water, irrigation and fishing schemes. ${ }^{67}$ Murowa Diamond Mine also constructed a $25 \mathrm{~km}$ lane dust road to link up the Murowa community with the Zvishavane-Rutenga Road. ${ }^{68}$ The construction of the road strongly improved accessibility of the Murowa community with shopping centres at Zvishavane Town. ${ }^{69}$ In this example, it is clear that mining enterprises can be of direct benefit to the communities where they are established. Such far-reaching infrastructural developments economically transform such communities by empowering them to accrue economic surplus for sale.

Colmer has asserted that many well developed countries have mining related industries which act as platforms for industrial development. ${ }^{70}$ Colmer has argued that it is through the extraction and processing of minerals that many of today's developed countries achieved massive industrialisation while some newly developed countries like China have rapidly developed because of venturing into mining locally and internationally. ${ }^{71}$ According to the World Bank Report, 2005, mineral extraction provided the bulk of African exports of mineral wealth as well as improving the living standards of local people as it provided African people with local jobs. ${ }^{72}$

Van Onselen and Phimister have argued that while large scale mining could have created employment in Africa, it brought with it devastating social effects such as illnesses, overcrowdedness and prostitution which were foreign ills. ${ }^{73}$ Both indigenous and immigrant labourers were exposed to epidermics such as Spanish Influenza due to poor health facilities for African employees in the mines. ${ }^{74}$ These epidermics claimed the lives of hundreds of African mine workers. ${ }^{75}$ Van Onselen and Phimister have stated that Spanish Influenza of 1918 dwindled the African population by $7 \%$ at Globe and Phoenix Mine in Kwe Kwe where 220 mine workers lost their lives. ${ }^{76}$ Ncube has also noted that Wankie and Kamativi Mines never bothered to build hospitals to cater for African mine workers during the initial stages of the establishment of mining enterprises in these respective areas. ${ }^{77}$ Racial segregationist policies introduced by the colonial regimes all over Africa denied African employees equal access to health facilities. Sometimes health care systems for African workers were completely non-existent. Working conditions for African workers were equally appalling. ${ }^{78}$ Living conditions for African employees were squalid and most African compounds were littered with communal water sources, tolets and bathrooms which were severely inadequate and dirty. ${ }^{79}$ Europeans further subjected Africans to the same racial arrogance and

\footnotetext{
65 World Bank Report, 2005, World development indicators, Washington, USA, p30

66 ibid

${ }^{67}$ Murowa Diamond Mine, 2008, Social Review Community Plan, p26

68 Ibid p27

${ }^{69}$ ibid

${ }^{70}$ Colmer B, 2000, Economic performance and public infrastructure, New York, USA, P188

71 ibid

${ }^{72}$ World Bank Report, 2005, World development indicators, Washington, p35

${ }^{73}$ Van Onselen and Phimister, 1978, Studies in the history of African mine labour in colonial Zimbabwe, Mambo Press, Gweru, p48

74 ibid

75 ibid

${ }^{76}$ ibid

${ }^{77}$ Ncube H, 2004, History of North western Zimbabwe 1850-1960, Mondi Books, Kadoma, p13

${ }^{78}$ Interview with RabsonYepe, former Lennox Mine employee, 23 January 2017

${ }^{79}$ ibid
} 
discrimination which existed in the wider Rhodesian society. ${ }^{80}$

Lennox Mine has however contributed tremendously towards the development of Mashava by the construction of four sections of houses in Lennox Village and these majestically stand out even today. ${ }^{81}$ Three sections of the housing units are located in the high density residential area. ${ }^{82}$ Section A consisted of 100 housing units while Section B consisted of 48 housing units. ${ }^{83}$ Section C has 100 housing units. ${ }^{84}$ The low density suburb of Lennox is located in the east close to the main road to Masvingo and consists of only 14 housing units reserved for senior management. ${ }^{85}$ Water and electricity was formerly installed by the European Capitalist oligarchic mining enterprise but was cut off as the electricity bill escalated to US $\$ 250000 .{ }^{86}$ Electricity has however been restored at the Mine Complex and the Mine Guest House and a payment plan to clear off the credit with ZESA has been successfully negotiated between the Mine General Manager, Edgar Mashindi and the supplier. ${ }^{87}$ Once funds are available it is envisaged that the housing units at Lennox Mine will have electricity and water restored fully. ${ }^{88}$

Presently Mining Partners of Lennox called Sponsors are involved in the process of resuscitation of the mine and they have contributed significant investment funds which have tremendously boosted gold production at Lennox. ${ }^{89}$ Each Mine Partner or Sponsor has a team of ten employees who harvest one ton of alluvial gold ore twice or thrice a week at an agreed cost of $30 \%$ of the end product being surrendered to Lennox Mine. ${ }^{90}$ Sponsors and their teams also have an agreed formula of sharing out the proceeds accruing after the ore has been processed and Fidelity Holdings has paid for the gold. ${ }^{91}$ These teams of employees have been offered accommodation at Lennox Village for rental by the former Lennox employees who claim ownership of the same housing units on the unchallenged belief that they are owed thousands of USA Dollars in unpaid salaries by Lennox Mine. ${ }^{92}$

Kenny Kwangwari, a former Lennox Mine employee has acknowledged that the local community benefitted tremendously from the provision of modern housing which the mine allocated to all workers. ${ }^{93}$ Currently former Lennox Mine employees still occupy these houses. ${ }^{94}$ The Lennox Mine management does not charge any rentals and former employees are very grateful for such an understanding. ${ }^{95}$ Former Lennox Mine employees however claim that they will continue to occupy the houses free of any charges because they are owed thousands of USA Dollars by Lennox Mine in salary and pension arrears. ${ }^{96}$ Hama Mahachi, the Chairman of Lennox Mine Union claims that he is owed nearly USA $\$ 900.00$ by Lennox Mine in salary arrears. ${ }^{97}$ Another former employee, Limon Mukuli, claims that he is owed USA\$4 000.00

\footnotetext{
${ }^{80}$ ibid

${ }^{81}$ Interview with Nyirenda, Lennox Mine Financial Manager, 22 January 2017

82 ibid

83 ibid

${ }^{84}$ ibid

85 ibid

${ }^{86}$ Interview with Edgar Mashindi, Lennox General Manager, 24 Janaury 2017

${ }^{87}$ ibid

88 ibid

${ }^{89}$ ibid

${ }^{90}$ ibid

91 ibid

${ }^{92}$ Interview with R. Yepe, former Lennox Mine employee, 23 January 2017

${ }^{93}$ Interview with Kenny Kwangwari, former Lennox Mine employee, 20 January 2017

${ }^{94}$ Interview with Edgar Mashindi, Lennox General Manager, 24 Janaury 2017

${ }^{95}$ Interview with Hama Mahachi, Former Chairman of the Lennox Mine Workers Union, 23 December 2016

96 ibid

${ }^{97}$ ibid.
} 
by Lennox Mine. ${ }^{98}$ Partmos Samambwa, a former employee also claims that Lennox Mine owes him USA $\$ 10000.00$ in salary arrears. ${ }^{99}$ It is this stalemate between Mine management and former employees over unpaid wages which probably explains the cutting off of essential services such as water and electricity to the housing units at Lennox Village. ${ }^{100}$

I visited the housing units and observed that they are modern and in an excellent state. Current Lennox Mine employees are also accommodated in these mine houses but pay rentals of about USA $\$ 30$ to USA $\$ 40$ per month per room to former employees who claim ownership of the same houses. ${ }^{101}$ The houses are spacious, well-ventilated and roofed with asbestos sheets. Although Lennox Mine ceased operations in 2006, Mahachi claims that houses in Section A and B have inside toilets and bathrooms connected to them and this ensures good sanitation for the occupants. ${ }^{102}$ However, presently water is not flowing in the tapes because former employees vandalised the pumps and stole pumping equipment at the Tugwi Waterworks years back. ${ }^{103}$ Women carry water on their heads or hire wheelburrows to fetch water from the business centre at Mashava. ${ }^{104}$ Others fetch untreated water from the Tugwi River. ${ }^{105}$ Even the Lennox Guest House is without water at the present moment. Management fetches water from the Great Zimbabwe University Waterworks in Gathsmine. ${ }^{106}$ Indeed, Great Zimbabwe University's arrival in Mashava explains the reasons for the resuscitation of formerly dilapidated housing units and infrastructure at Gathsmine. ${ }^{107}$ Great Zimbabwe University operates its largest campus at Mashava and is responsible for pumping clean water all over in Mashava. ${ }^{108}$ Over two thousand university students now live in the revamped former mine houses in Gathsmine. ${ }^{109}$

Lennox Mine constructed gravel roads to link the mine with the local community. ${ }^{110}$ There are two main gravel roads linking Lennox Mine with the Masvingo to Bulawayo Highway. ${ }^{111}$ One of the roads stretches from the mine eastwards and passes through the low density residential area of Lennox Village. The other one is located in the west and also passes through the high density residential area of Lennox Village leading into the Masvingo-Bulawayo Highway. Two small bridges were constructed along these two roads to connect Lennox Mine with Mashava Business Centre, Empress Village as well as the rest of the Chivi District to Mhandamabwe or Chief Bere area. ${ }^{112}$ According to the 2000 Lennox Mine Community Review Plan, the bridges provided direct access for vehicles to transport workers and commuters from Lennox Mine to the Mashava Business Centre and beyond. ${ }^{113}$ The roads which were constructed by the mine improved accessibility for commuters to carry out their daily business across Mashava and beyond. Commuter kombis and buses now plighed the route carrying passengers to their respective destinations. ${ }^{114}$

\footnotetext{
98 Interview with Limon Mukuli, former Lennox Mine employee, 22 December 2016

${ }^{99}$ Interview with Partmos Samambwa, former Lennox Mine employee, 23 December 2016

${ }^{100}$ Interview with Hama Mahachi, Former Chairman of the Lennox Mine Workers Union, 23 December 2016

101 ibid

102 ibid

103 ibid

104 ibid

105 ibid

${ }^{106}$ Interview with Edgar Mashindi, Lennox General Manager, 24 Janaury 2017

${ }^{107}$ Interview with Professor Rungano Zvobgo, Vice Chancellor, Great Zimbabwe University, 23 January 2017

108 ibid

109 ibid

${ }^{110}$ Interview with Innocent Nyikadzino, former Lennox Mine employee, 12 December 2016

111 ibid

112 ibid

${ }^{113}$ Lennox Gold Mine, Community Review Plan, Mashava, 2000, p20

${ }^{114}$ Interview with Huruva, Lennox Mine Partner and Sponsor, 14 December 2016
} 
Emmanuel Mabika claims that the roads have enabled women and unemployed youths to carry out different self-sustaining projects such as poultry rearing, market gardening and vendors now transport large loads of vegetables, fruits and other paraphanelia for sale at both Lennox Mine and Mashava Business Centre. ${ }^{115}$ Mabika also indicated that farm produce from Gutsaruzhinji Irrigation Scheme in Chivi were ferried through these two main roads. ${ }^{116}$ According to Nemamwa Rural Council Records, although accessibility to Lennox Village was improved, Lennox Mine had promised residents to refurbish the roads using tar to reduce the effects of using bumby and dusty roads but this has not so far materialised. ${ }^{117}$ Most people whose houses are located in the vicinity of these roads complained of problems associated with dust. ${ }^{118}$ Lennox Gold Mine Social Review Community Plan also maintains that the Mine had plans to fence the roads so as curb loss of both human and animal life. ${ }^{119}$ To date the roads remain unfenced and Anna Tarusenga, a Lennox Village resident claims that her daughter was run over by a car in 2002 on her way back from school. ${ }^{120}$ Titus Chitonga, a Chivi communal farmer also claims that a hauage truck ran over his head of cattle in $1998 .{ }^{121}$

According to Lennox Gold Mine Social Review Community Plan, Lennox Mine had a mandate to provide healthcare for all the company employees and their dependents. ${ }^{122}$ In acordance with this agreement, Lennox Mine built two clinics for the benefit of the mining community as well as for local people in and around Mashava. ${ }^{123}$ One clinic was constructed on the mine complex to cater for mine workers and their dependents. ${ }^{124}$ The other clinic was constructed at Bere Village to cater for local community. ${ }^{125}$ Dickson Rusere confirmed that the clinic at Bere greatly benefitted the local community as it provided treatment for various ailments including the dreaded syphilis, gonorrhea, genital herpes and other sexually transmitted infections which became rampant in and around Mashava. ${ }^{126}$ The two clinics also ran immunisation programmes to curb the six child killer diseases. ${ }^{127}$ Dickson Rusere argued that even though the construction of the two clinics was indeed a blessing, there was often shortages of essential drugs at both clinics. ${ }^{128}$ Both clinics also failed to cope with the large population at Lennox Village and Bere. ${ }^{129}$ The Mine Management introduced stringent rules and regulations at Lennox Village in connection with the number of dependents each household was supposed to have at any one time. ${ }^{130}$ Every visitor was now required to have a pass from the Mine security to allow him or her to stay at the Lennox Village for a specific period. ${ }^{131}$ Once the period granted to the visitor expired they were supposed to vacate the village and return to wherever they had come from. ${ }^{132}$ The movement of non-residents in and out of the Lennox Village was meant to be a mechanism for disease control and management. ${ }^{133}$

\footnotetext{
${ }^{115}$ Interview with Emmanuel Mabika, former Lennox Mine employee, 14 December 2016

116 ibid

${ }^{117}$ Nemamwa Rural Council Report, 30 December 2004

${ }^{118}$ Interview with Kudakwashe Mafa, former Lennox Mine employee, 15 December 2016

${ }^{119}$ Lennox Gold Mine Social Review Community Plan, 2000, p20

${ }^{120}$ Interview with Anna Tarusenga, Lennox Village resident, 23 December 2016

${ }^{121}$ Interview with Titus Chitonga, peasant Farmer, Chivi, 6 December 2016

${ }^{122}$ Lennox Gold Mine Social Review Community Plan, 2000, p20

123 ibid

124 ibid

125 ibid

${ }^{126}$ Interview with Dickson Rusere, former employee, Lennox Village, 18 December 2016

127 ibid.

${ }^{128}$ ibid

${ }^{129}$ ibid

${ }^{130}$ Interview with Hama Mahachi, Former Chairman of the Lennox Mine Workers Union, 23 December 2016

131 ibid

132 ibid

133 ibid
} 
A number of dvelopment projects were set in place by Lennox Mine to assist Karanga people who had been displaced from the area where the mining complex was located. ${ }^{134}$ I will adapt the World Bank Template for assessing the benefits accruing from Lennox Gold Mine. ${ }^{135}$ The template classifies development projects in the following categories : physical infrastructure, education, health and local enterprise development. ${ }^{136}$

Lennox Mine also contributed significantly towards human resources training and this is an essential aspect of economic development of any country. Lennox Mine employees received on the job training including apprenticeship training in the various related fields such as carpentry, building, electric and diesel plant fitting and many others. ${ }^{137}$

Above this, Lennox Mine also contributed funding towards agricultural development and hence these two aspects have also been added on to the table below showing how Lennox Mine contributed funding towards the development of the Zimbabwean economy.

\begin{tabular}{|c|c|c|c|}
\hline Area of Development & $\begin{array}{l}\text { Project funded by } \\
\text { Lennox Mine }\end{array}$ & $\begin{array}{l}\text { Amount invested on the } \\
\text { project [ZMD] }\end{array}$ & $\begin{array}{l}\text { Proportion in total } \\
\text { percentage [\%] }\end{array}$ \\
\hline Water Reticulation & $\begin{array}{lr}\text { Water } & \text { supply, } \\
\text { installation } & \text { and } \\
\text { purification } & \end{array}$ & $\$ 241000000.00$ & 29.6 \\
\hline $\begin{array}{l}\text { Roads and other } \\
\text { infrastructure }\end{array}$ & $\begin{array}{l}\text { Construction of gravel } \\
\text { roads in and around the } \\
\text { mine complex }\end{array}$ & $\$ 51000000.00$ & 6.2 \\
\hline Education & $\begin{array}{l}\text { Provision of resources } \\
\text { towards construction of } \\
\text { schools and } \\
\text { maintenance services }\end{array}$ & $\$ 239000000.00$ & 29.6 \\
\hline $\begin{array}{l}\text { Community } \\
\text { Development }\end{array}$ & $\begin{array}{ll}\text { Donations } & \text { to } \\
\text { Community projects }\end{array}$ & $\$ 94000000.00$ & 11.6 \\
\hline $\begin{array}{l}\text { Community } \\
\text { Development }\end{array}$ & $\begin{array}{l}\text { Expenditure on public } \\
\text { consultations }\end{array}$ & $\$ 70000000.00$ & 8.6 \\
\hline $\begin{array}{ll}\text { Agricultural } & \text { and } \\
\text { pastoral activities } & \end{array}$ & $\begin{array}{l}\text { Agricultural and animal } \\
\text { husbandry services }\end{array}$ & $\$ 12000000.00$ & 1.5 \\
\hline $\begin{array}{l}\text { Training and capacity } \\
\text { building }\end{array}$ & $\begin{array}{ll}\begin{array}{l}\text { Human } \\
\text { development }\end{array} & \text { resources } \\
\end{array}$ & $\$ 49000000.00$ & 6.0 \\
\hline
\end{tabular}

Source : Anglo-American Report, 2004

According to Lennox Gold Mine Social Review Community Plan, 2000, Lennox Mine paid ZMD\$3,3 billion in compensation towards the relocation and resettlement for those villagers who were moved from the Lennox Mine Complex. ${ }^{138}$ From the 1990s Lennox Mine was spending an average of nearly ZMD\$12 700.00 monthly towards development projects in Mashava. ${ }^{139}$ Furthermore, more than half of Lennox Mine's budget was spent towards water reticulation and education. ${ }^{140}$

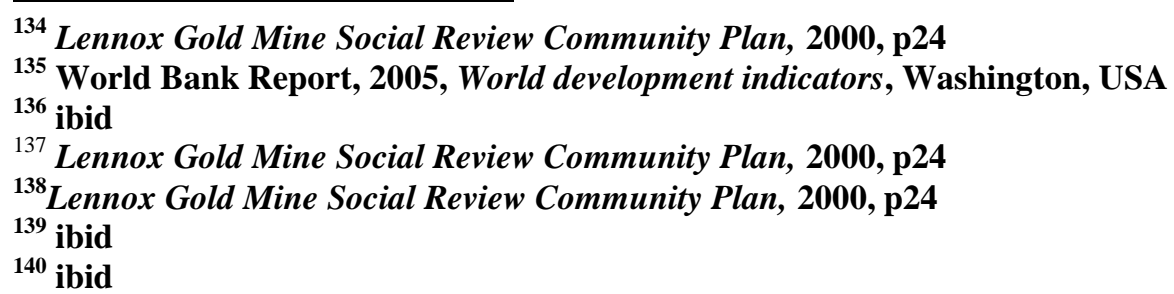


Lennox Mine also funded environmental protection projects. ${ }^{141}$ According to Linus Chikara Lennox Mine provided funding to various Lennox Villages for the purposes of planting and caring for mango trees. ${ }^{142}$ Lennox Mine also funded training to local people for the cultivation and provision of saplings in its endeavour to promote a green belt in Mashava. ${ }^{143}$ Villagers received saplings and training to conduct planting and caring for the fruit trees. ${ }^{144}$ This environmental management programme was a great success and explains the large number of fruit trees that are still in existence all over Mashava today. ${ }^{145}$

In order to boost employment creation in Mashava, Lennox Mine supported the local economy by encouraging residents to embark on artisanal mining of alluvial gold ore. ${ }^{146}$ No sooner had Lennox Mine started on this community project than the Zimbabwean Government gazetted a law which outlawed the manual extraction of gold in areas designated for industrial exploration. ${ }^{147}$ After the artisanal alluvial gold mining project ceased Lennox Mine also introduced a loan scheme to finance individual business enterprises in Mashava. ${ }^{148}$ From 1999 to 2003, about 85 Mashava citizens recieved small loans from Lennox Mine to start various small and medium sized business enterprises. ${ }^{149}$ By 2003, approximately ZMD\$42.5 million was paid out by Lennox Mine for small and medium sized business enterprises. ${ }^{150}$ Lennox Mine Management claim that only one third of the capital loan issued out to Mashava community business leaders was repaid, the rest of the loan applicants defaulted on their payments and this project thus suffered a natural death. ${ }^{151}$

Lennox Mine also funded educational programmes in Mashava and in particular the following schools received substantial financial assistance from the mine, Mashaba Primary and Bere Secondary Schools. ${ }^{152}$ Lennox Mine contributed about ZMD\$239 Million towards education between 1996 and 2004. ${ }^{153}$ Lennox Mine also constructed a classroom block at Bere School in $1986 .{ }^{154}$ Lennox Mine also repaired a classroom block whose roof was blown off by wind at Bere Secondary School in 2003. ${ }^{155}$ Lennox Mine assisted all the above mentioned schools with stationary throughout the period of the mine's existence. ${ }^{156}$ Above this, Lennox Mine funded a bus to ferry school children from Gathsmine, Empress and other Mashava surburbs to school on a daily basis during term times. ${ }^{157}$

It cannot be contested that Lennox Mine directly and indirectly supported employment creation in Mashava. This research cannot establish with clinical exactitude the actual numbers of people who were gainfully employed in Mashava through Lennox Mine initiatives. Both oral and documentary sources are inconsitent on the total number of empoyees contracted by Lennox Mine. Variation between estimates is likely to derive from the fact that the number of employees have shifted overtime and that different estimates reflect different points in time. In addition, the definition of a mine job always varies. Some

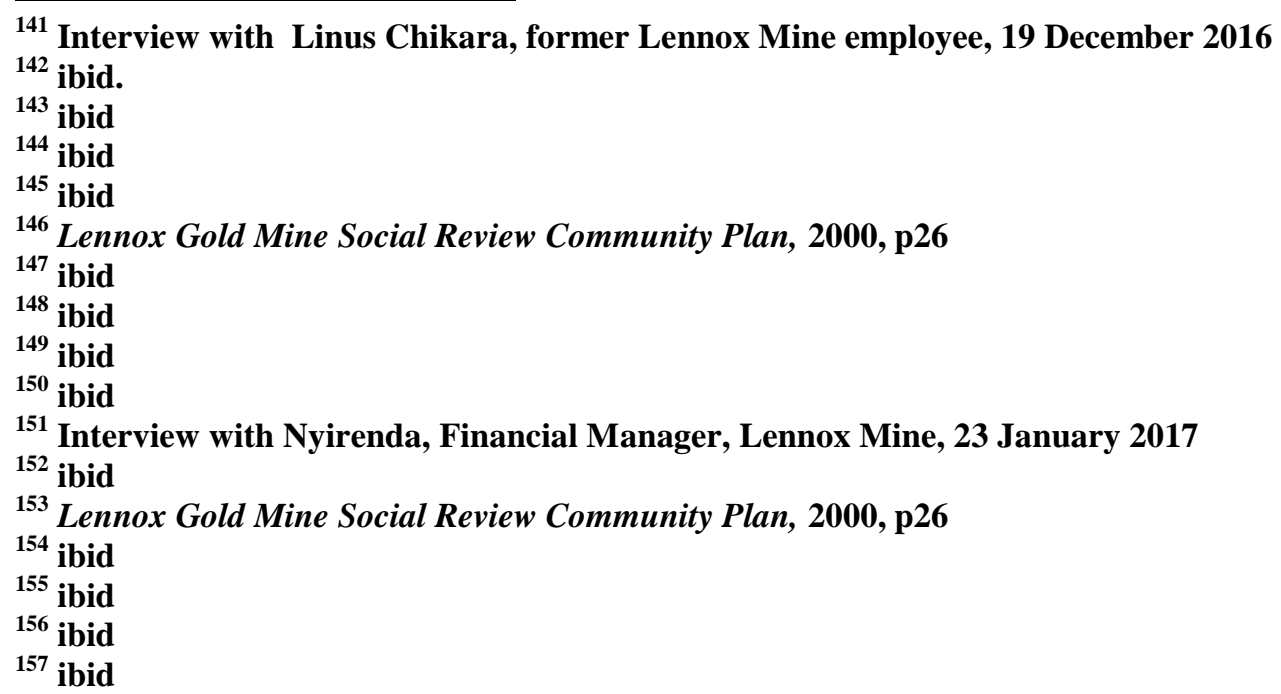


sources only counted those employed by Lennox and were directly involved in mining operations. Other sources included all those jobs that were created through direct financial injection by Lennox Mine. Even at Lennox Mine, there were two main employers : Lennox Mine and its main contractor, Murray and Roberts. $[\mathrm{M} \& \mathrm{R}]]^{158}$ Documentary records indicate that Lennox Mine employed around 680 mine workers while M\&R employed only 331 workers. ${ }^{159}$

The World Bank assesses benefits streaming from mining and distinguishes between direct and indirect employment in relation to a mining operation. ${ }^{160}$ According to this definition, persons working for the operating company are direct employees, while persons working for firms to which the operating companies have contracted out certain tasks are indirectly employed. In addition to direct and indirect employment Lennox Mine also generated a number of jobs as a result of investments by the company in the surrounding areas during the mine's inception and during the operational phase. ${ }^{161}$ The operation of the mining enterprise also stimulated jobs induced from the ways which employees spent their earnings. The World Bank Report calls this induced employment. ${ }^{162}$ In 2000, Lennox Mine hired 800 workers to construct the mining complex and the related infrastructure. ${ }^{163}$

\section{Closure of Lennox Mine in 2006}

The reasons for the closure of Lennox Mine by the European mine owners, Reedbuck, a subsidiary of the Anglo-American Corporation are not clearcut. Some informants indicate that the owners made enough profit from gold sales and underpayment of workers that they decided to relocate abroad where they invested the newly found wealth in various businesses, especially in Australia. ${ }^{164}$ Some claim that the owners repartriated hundreds of pure gold bars to Australia and fled Zimbabwe. ${ }^{165}$ The Mine was also probably closed in 2006 due to a number of reasons associated with the Zimbabwean Government interférences with private companies. ${ }^{166}$ Alois Chidenga claims that Lennox Mine closed in 2006 due to legislative bungling by the Zimbabwean Government. ${ }^{167}$ The Government of Zimbabwe indeed introduced a number of legislative measures to promote indigenous ownership of the means of production especially after $2000 .{ }^{168}$ Some of the mechanisms impacted negatively on the performance of the Zimbabwean economy and triggered capital and investment flight to countries with favourable economic investment climate such as Botswana, Namibia and South Africa. ${ }^{169}$ While the spirit of black economic empowerment was positive and progressive, the manner in which it was handled by the Mugabe regime caused an economic meltdown of the Zimbabwean economy clearly visible to date. ${ }^{170}$ Nearly 3 million Zimbabwean economic refugees fled into exile mostly into neighbouring South Africa but others are now domiciled in Botswana, Namibia and countries of the European Union. ${ }^{171}$ The Zimbabwean economic

\footnotetext{
158 ibid

159 ibid

${ }^{160}$ World Bank Report, 2005, World development indicators, Washington, USA

161 ibid

162 ibid

163 ibid

${ }^{164}$ Interview with Innocent Nyikadzino, former mine employee, 2 January 2017

165 Interview with Wellington Muzenda, Legal practitioner, Mashava, 20 January 2017

${ }^{166}$ Interview with Tasara Muguti, Lecturer in Economic History at Great Zimbabwe University, 21 Janaury 2017

${ }^{167}$ Interview with Alois Chadenga, former Lennox Mine employee, 26 Janaury 2017

${ }^{168}$ Interview with Tasara Muguti, Lecturer in Economic History at Great Zimbabwe University, 21 Janaury 2017
}

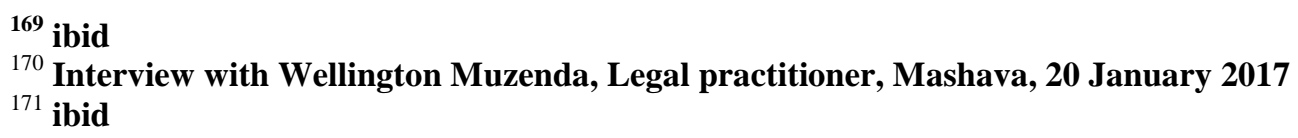


meltdown created a chaotic environment unsuitable for luring investment into the country especially after the massive dispossession of European owned farming land. ${ }^{172}$

The Government of Zimbabwe in its quest to correct the wrongs of colonialism introduced legislative mechanisms through its overzealous former minister of Indigenization and Empowerment, Honourable Saviour Kasukuwere, which forced privately companies to cede a $51 \%$ share of their holdings to indigenous peoples. ${ }^{173}$ The consequences of this short sighted economic blueprint have proved disastrous for the Zimbabwean economy which is now in its doldrums. ${ }^{174}$ Only members of the ruling oligarchy seem to have benefitted from this scandalous scheme and just like the land redistribution policy this later private - company - grabbing scheme also met with outright failure as private owners simply retaliated by withdrawal of capital and funding causing many companies to collapse. ${ }^{175}$ What now remains on the ground in most of Zimbabwean urban areas are empty and dilapidated company premises stripped bare of all machinery and equipment which was misappropriated by the incubent black entrepreneurs who grabbed formerly the owned private companies. ${ }^{176}$

A similar situation occurred at Lennox Mine in 2006. European owners refused to cede the required 51\% shares to black entrepreneurs and of course the law took its course. ${ }^{177}$ The mine owners claimed that Lennox Mine was a private holding but the Honourable Minister of Indigenous and empowerment, Saviour Kasukuwere issued an ultimatum for the European capitalist holders to vacate the mining complex. ${ }^{178}$ The mine was then awarded to Honourable Deputy Mininster of Mines, Engineer Gandiwa Moyo a shrewd entrepreneur who has steered the mining complex from its former position of economic collapse to the current state where it is producing significant gold tonnage which is directly benefitting and funding Zimbabwean Government coffers. ${ }^{179}$ Lennox Mine sells its gold to Fidelity, which is a Zimbabwean Government owned enterprise. ${ }^{180}$

The Lennox Mine General Manager, Edgar Mashindi has set in motion a scheme which has incorporated citizens, civil leaders, business people, civil servants, military leaders and all aspiring entrepreneurs in joining Lennox Mine as financial partners in gold production on a large scale. ${ }^{181}$ Each member of this team of partners also called Sponsors, employs a group of miners who are contracted to extract alluvial gold ore at Lennox Mine under the supervision of the mining manager, Engineer Zvabvirepi. ${ }^{182}$ Engineer Zvabvirepi is responsible for carrying out all the blasting duties in the mine tunnels and the job of contracted teams is simply to collect and pack the alluvial gold ore into containers for transport to the surface where it is then shipped to Chaka Milling Company or Texas Milling Company. ${ }^{183}$ Both Texas and Chaka Milling Companies are located in Masvingo Province. ${ }^{184}$ Chaka Milling Company is located about $50 \mathrm{~km}$ from Mashava on the Masvingo City to Bondolfi Road while Texas Milling Company is situated only four kilometres west of Mashava on the Mashava to Bulawayo Highway. ${ }^{185}$

\footnotetext{
${ }^{172}$ Interview with Tenson Tawanda Mugodzwa, Lecturer Gender and Development Studies at Midlands State University, Gweru, 4 January 2017

173 ibid

174 ibid

175 ibid

${ }^{176}$ ibid

177 Interview with Silas Magwizi, Businessman, Mashava, 2 February 2017

${ }^{178}$ Interview with Vengesai Vheremu, former Lennox Mine employee, 4 January 2017

${ }^{179}$ Interview with Wellington Muzenda, Legal practitioner, Mashava, 20 January 2017

${ }^{180}$ Interview with Edgar Mashindi, Lennox Mine General Manager, 12 December 2017

${ }^{181}$ Interview with Nyirenda, Financial Manager, Lennox Mine, 3 February 2017

182 ibid

183 ibid

${ }^{184}$ ibid

185 ibid
} 
Both milling companies are owned and administered by black Zimbabwean entrepreneurs. ${ }^{186}$ Alluvial gold ore is transported from Lennox Mine by haulage trucks and Lennox Mine provides all documentation and security supervision throughout the milling and processing cycle. ${ }^{187}$ Transport, milling and processing of the alluvial gold ore is financed by the Mine Partners or Sponsors. ${ }^{188}$ Lennox Mine as the senior partner provides the alluvial gold ore, its transportation from underground to the surface and security to escort the trucks carrying the ore to its processing destination. ${ }^{189}$ Representatives of the respective teams of miners are always present from the first stage of loading the ore at the mine surface to the last stage of payment for the gold extracted by Fidelity. ${ }^{190}$

Lennox Mine only claims a mere $30 \%$ of the total cost paid out for the gold by Fidelity while the Mine Partners and their respective teams receive $70 \%$ from the sale of gold to Fidelity. ${ }^{191}$ Lennox pays for all security services and mine engineering costs including procurement of blasting equipment and other paraphernalia. ${ }^{192}$ From 2006 Lennox Mine has not recorded any accident related to its gold mining enterprise. Mining personnel are adequately trained and supervised to carry out their different but difficult tasks.

Mashava community is contented by the manner in which Lennox Mine has incorporated indigenous people in its mining enterprise. ${ }^{193}$ Civil servants, civic leaders, members of the civil service, teachers, lecturers, nurses doctors, lawyers and even Members of Parliament are partners of Lennox Mine and have their respective teams extracting gold at Lennox Mine. I even interviewed two prominent Members of Parliament who belong to the opposition MDC - T Party who expressed gratitude to Engineer Gandiwa Moyo for allowing ordinary citizens from all over Zimbabwe to join hands in sponsoring and benefitting from gold mining which used to be reserved only for Europeans. These Sponsors, members of the respective teams of miners and community leaders have applauded Honourable Deputy Minister, Engineer Gandiwa Moyo as a modern reformer, entrepreneur par excellence and a great vsionary leader. Many others have single-handedly applauded the wise and capable leadership of the Lennox General Manager, Edgar Mashindi, as positive and fair. Edgar Mashindi holds regular consultative meetings with both Mine Partners and their employees. ${ }^{194}$ At these meetings usually held at Greta Park under social and conducive environment, Edgar Mashindi and his team receive feedback from Mine Sponsors and records their views and recommendations. The concerns of Mine Partners are given serious considerations as these Sponsors have invested large portitons of their individual savings to sustain and finance the mining and processing requirements of the alluvial gold ore. ${ }^{195}$ For example, it is the Mine Partners who pooled their financial resources to pay off the $\$ 250000.00$ ZESA bill incurred by Reedbuck Mining Corporation which led to the cutting off of electricity supply to the mine. ${ }^{196}$

Currently Mashava is now a hive of activity, thanks to the resuscitation of the mining operations by the new management. ${ }^{197}$ Former Lennox Mine workers have been re-incorporated as miners or security personnel at the mine because of their previous experience gained at the same mine. ${ }^{198}$ Environmental

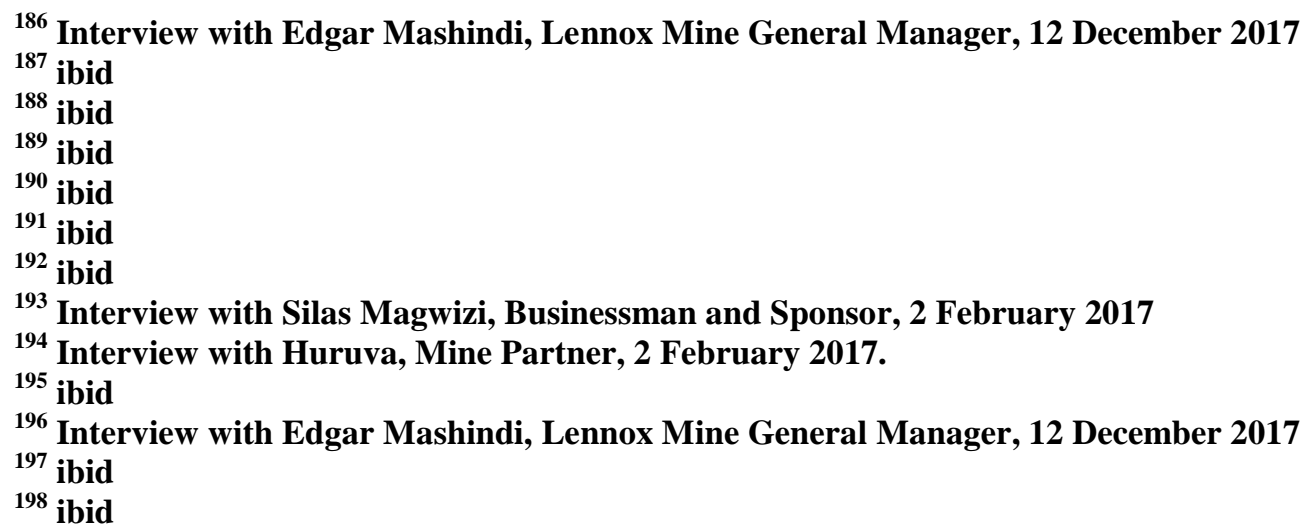


consideration receive great attention from the mine management who have banned and continue to monitor all illegal surface mining, called Chikorokoza, by local people. [Artisanal mining]. Chikorokoza was detrimental to the environment as it encouraged local people to open up mining pits all over Mashava and these pits claimed the lives of ordinary people and many animals were trapped and died in these pits ${ }^{199}$ The pits flooded up during the rain season and have become the haven for mosquitos. ${ }^{200}$ Every monthend hordes of traders and flea market entrepreneurs from all over Zimbabwe converge and camp overnight at Mashava selling their respective wares ranging from clothes, kitchen wares, cars, domestic products and other related paraphernalia. ${ }^{201}$ This is adequate testimony that Lennox Mine, a stone's throw from Mashava Business Centre is now a booming economic giant contributing significantly to the growth and development of the Zimbabwean economy. A magistrate Court was recently opened at Mashava to deal with crime associated with a booming economy. ${ }^{202}$ Hundreds of youths from all over Zimbabwe have found employment at Lennox Mine.

\section{Conclusion}

This research has attempted to show that Lennox Mine once closed in 2006 has like a Phoenix resurrected and has become a booming mining centre contributing significant gold earnings to the ailing Zimbabwean economy. Mashava has benefitted tremendously from the re- opening of Lennox Mine and has started shedding - off its ghost town trademark due to the entrepreneurship and leadership of its current visionary owner, Honourable Deputy Minister of Mines, Engineer Gandiwa Moyo whose policy of incorporating local ordinary indigenous people in wealth generation has paid dividends. Hundreds of formerly unemployed youths have rendezvoused at Lennox where prospects of gettings jobs as miners has been opened. Others have converged on Mashava to open shop as traders in small scale and medium-sized businesses. Mashava has been this port of call because it offers excellent accommodattion in the many housing units left vacant by the defunct Asbestos Mining Company bought off by Mutumwa Mawere. Asbestos Mining ceased at both Gathsmine and King Mine due to bureacratic bungling between Mutumwa Mawere and the Government of Zimbabwe. Lennox Mine runs its own housing programme even though former Lennox Mine employees have refused to vacate the same houses for the reasons that they are owed thousands of USA dollars over unpaid salaries.

\section{$\underline{\text { References }}$}

\section{A. Primary Sources : Oral interviews}

Chadenga A, former employee, Lennox Mine, 26-01-2017

Chadzamira E, Member of Parliament, Mashava, 21-01-2017

Chief Bere, Bere area, 13-01-2017

Chikara L, former employee, Lennox Mine, 19-12-2016

Chitongo T, peasant farmer, Chivi area, 06-12-2016

Gandiwa T, Director, Lennox Mine, 06-01-2016

Huruva J, Lennox Mine Sponsor, 14-12-2016

Kechi R, Lennox Mine Village, 12-01-2017

Kwangwari K, former employee, Lennox Mine, 20-01-2017

Mabika E, former employee, Lennox Mine, 14-12-2016

Mafa K, former employee, Lennox Mine, 15-12-2016

Magwizi S, Businessman and Sponsor, 20-01-2017

Mahachi H, former Chairman, Lennox Mine Workers Union, 23-12-2016

Mashindi E, Lennox Mine General Manager, 02-1-2017

Mawere M, former owner Gathsmine and King Mine, South Africa, 22-01-2017

\footnotetext{
${ }^{199}$ Interview with Silas Magwizi, Businessman and Sponsor, 2 February 2017

200 ibid

201 ibid

202 ibid
} 
Muganje T, Businessman, Highway Nightclub, Mashava, 16-01-2016

Mugodzwa T T, Lecturer, Midlands State University, Gweru, 02-02-2017

Muguti T, Lecturer, Great Zimbabwe University, Mashava Campus, 12-01-2017

Muguti C, peasant farmer, Chivi area, 21-01-2017

Mukuli L, former employee, Lennox Mine, 22-12-2016

Muzenda W, Legal Practitioner, Masvingo, 20-01-2017

Nyikadzino I, former employee, Lennox Mine, 12-12-2016

Nyirenda, Lennox Mine Financial Manager, 22-01-2017

Professor Zvobgo R, Vice Chancellor, Great Zimbabwe University, 23-01-2017

Rusere D, former employee, Lennox Mine, 22-01-2017

Tarusenga A, Lennox Mine Village, 21-12-2016

Samambwa P, former employee, 23-12-2016

Vheremu V, former employee, 01-02-2017

Yepe R, former employee, Lennox Mine, 22-01-2017

Yepe W, former employee, Lennox Mine, 23-01-2017

\section{B. Archival sources: Zimbabwe National Archives, Harare}

Monthly Reports

1. N9/4

2. N9/4/1-45. [Up to 1923]

\section{Quarterly Reports}

1. N9/3

2. N9/3/1-3. [Up to1900]

\section{Half-yearly Reports}

1. $\mathrm{N} 9 / 2$

2. N9/2/1-3. [Up to 1913]

\section{$\underline{\text { Annual Reports }}$}

1. $\mathrm{N} 9 / 1$

2. N9/1/1-26 [Up to 1923$]$

\section{Native Department Files [Charter.]}

1. NSK Files

2. NSK1/1/1-3 [1898-1905]

\section{Secondary sources : Articles, Books and Mine Publications}

1. Anglo-American Report, 2008, World development indicators, Journal for Sustainable Development, London

2. Anglo-American Report, 2004, Reedbuck Lennox Mine

3. Aschauer D A, 1980, Public expenditure and production, Journal of Monetary Economics, USA

4. Beach D N, 1977, The Shona economy: branches of production, in R. Palmer and N. Parsons, [eds], The roots of rural poverty in Central and Southern Africa, Heinemann, London.

5. Colmer B, 2008, Economic performance and public infrastracture, New York

6. Lennox Mine Goldmine, Social Review Community, Journal of Community Development, Mashava

7. Microsoft Encarta Encyclopedia, 2000, Mining benefit streams, Washington, USA

8. Mining Indaba, 2008, Global perspectives on mining, Journal of Sustainable Development, Bulawayo

9. Ncube, H, 2004, History of North western Zimbabwe, 1850-1960, Mondi Books, Kadoma

10. Van Onselen and Phimister I, 1978, Studies in the history of African mine labour in colonial Zimbabwe, Mambo Press, Gweru

11. World Bank Report, 2005, World development indicators, USA 